\title{
THE ASSOCIATION OF KIDNEY STRESS TEST WITH WATER SALT LOADING WITH ESTIMATED GLOMERULAR FILTRATION RATE DECLINE IN PATIENTS WITH CHRONIC KIDNEY DISEASE STAGE 1-3
}

\author{
Dmytro IVANOV ${ }^{1}$, Liybov SAVYTSKA ${ }^{2,1} \bowtie$, Veronika KULACHEK ${ }^{3}$ \\ ${ }^{1}$ Shupyk National Medical Academy of Postgraduate Education, Department of Nephrology and Renal \\ Replacement Therapy, Kyiv, Ukraine \\ ${ }^{2}$ Municipal institution of Kyiv Regional Council «Kyiv Regional Hospital № 2», Department of Therapy, \\ Kyiv, Ukraine \\ ${ }^{3}$ Higher State Educational Establishment of Ukraine „Bukovinian State Medical University“, Department \\ of Internal Medicine and Infectious Diseases, Chernivtsi, Ukraine
}

Received 06 May 2019, Accepted 27 July 2019

https://doi.org/10.31688/ABMU.2019.54.3.06

\section{Abstract}

Introduction. Kidney Disease Outcomes Quality Initiative (KDIGO) Group proposes the estimated glomerular filtration rate (eGFR) and albuminuria rate for a combined risk of clinical outcomes in patients with chronic kidney disease (CKD). However, the decline rate of eGFR can vary independently of the baseline eGFR.

The objective of the study was to improve the prognostic efficacy in chronic kidney disease (CKD) stage 1-3 due to new significant factors of CKD progression detected by renal stress test via the water-salt loading with $0.5 \%$ sodium chloride solution, at a rate of $0.5 \%$ of the body weight.

Material and methods. In a single-centre prospective study, during 3-year follow-up period, from January 2016 to December 2018, 108 patients with CKD stage 1-3 (a, b) were examined. There were two groups: patients with rapidly progressive CKD whose

\section{Résumé}

Test de stress rénal avec la charge d'eau salée et son association avec le déclin du débit de filtration glomérulaire estimé chez les patients avec de la maladie rénale chronique en stade $1-3$

L'objectif de l'étude. Le groupe KDIGO propose le DFGe et l'albuminurie pour évaluer le risque combiné des résultats cliniques. Cependant, le déclin du DFGe peut varier indépendamment du DFGe de base. On a eu le but d'améliorer l'efficacité du pronostic chez les patients avec la maladie rénale chronique de stade 1-3 à l'aide de nouveaux facteurs pronostiques significatifs de la progression de la maladie rénale chronique détectés pendant le test de stress rénal via la charge d'eau salée avec une $0,5 \%$ solution de chlorure de sodium au taux de $0,5 \%$ du poids du corps.

Méthodes. Dans une étude prospective monocentrique, 108 patients atteints de maladie rénale 
eGFR throughout one-year follow-up decreased by 3 $\mathrm{ml} / \mathrm{min} / 1.73 \mathrm{~m}^{2}$ and more (59 patients), and the group with a stable CKD, whose eGFR throughout one-year follow-up did not decrease or has decreased by less than $3 \mathrm{ml} / \mathrm{min} / 1.73 \mathrm{~m}^{2}$ (49 patients).

Results. No relationship between the renal functional reserve, stimulated GFR and a decline in eGFR throughout the year was found. The change in urine creatinine on the background of the water-salt loading was positively correlated with changes in eGFR throughout the year. Spearman's correlation coefficient was rs 0.4 (p-0.02). The OR of decline in eGFR by more than $3 \mathrm{ml} / \mathrm{min} / 1.73 \mathrm{~m}^{2}$ throughout the year, with a decrease in urine creatinine level by more than $2 \mathrm{mmol} / \mathrm{L}$, was 4.7 (95 \% CI 1.9-12.0).

Conclusions. Improving the functionality of the renal stress test via the water-salt loading by measuring urine creatinine can help to identify the high-risk group for disease progression.

Keywords: chronic kidney disease, renal stress test, water-salt load, renal functional reserve.

\author{
List of abbreviations: \\ CKD - chronic kidney disease \\ RFR - renal functional reserve \\ eGFR - estimated glomerular filtration rate
}

\section{INTRODUCTION}

The prevalence of chronic kidney disease increases progressively with age, affecting about half of persons over 70 years old ${ }^{1}$, because of the increase in the incidence of diabetes mellitus ${ }^{2}$ and arterial hypertension $^{3}$, as one of the determining factors in the development of end-stage chronic kidney disease (CKD).

The KDOQI (Kidney Disease Outcomes Quality Initiative) Guidelines identify the progression of kidney disease as a reduction of the renal function, assessed by determining the glomerular filtration rate (GFR), creatinine clearance or serum creatinine, in a patient who was examined with probable and comparative methods over time, or the onset of renal failure, which is determined by initiation of renal replacement therapy or by symptoms or complications of reduced renal function ${ }^{4}$.

Currently, according to the recommendations of the KDIGO Expert Group (Kidney Disease Improving Global Outcomes) ${ }^{5}$, the criteria for estimated glomerular filtration rate and the rate of albuminuria are used for a combined risk evaluation of renal consequences and other complications. chronique de stade $1-3$ (a, b) ont été examinés. Il y avait deux groupes : les patients atteints de la maladie rénale chronique progressive, dont le DFGe au cours du suivi a diminué de $3 \mathrm{ml} / \mathrm{min} / 1,73 \mathrm{~m}^{2}$ et plus (59 patients), et le groupe avec une maladie rénale chronique stable dont le DFGe au cours d'un an n'a pas diminué ou a diminué de moins de $3 \mathrm{ml} / \mathrm{min} / 1,73 \mathrm{~m}^{2}$ (49 patients).

Résultats. On n'a pas trouvé de relation entre la réserve fonctionnelle rénale, le DFGe stimulé et le déclin du DFGe dans un an. La variation de la créatinine urinaire pendant la charge d'eau salée était positivement corrélée aux variations du DFGe pendant un an (p 0,02). Le rapport de chances du déclin de DFGe de plus de $3 \mathrm{ml} / \mathrm{min} / 1,73 \mathrm{~m}^{2}$, en cas de diminution du taux de créatinine dans l'urine de plus de $2 \mathrm{mmol} / \mathrm{L}$, est 4,7 (IC 95\%: 1,9-12,0).

Conclusions. L'amélioration du test de stress rénal via la charge de l'eau salée avec l'évaluation de la créatinine dans l'urine peut aider à identifier le groupe à haut risque de progression de la maladie rénale chronique.

Mots-clés: la maladie rénale chronique, la progression, le test de stress rénal, la charge d'eau salée, la réserve fonctionnelle rénale

Abréviations: $\mathrm{MRC}$ - la maladie rénale chronique, RFR - la réserve fonctionnelle rénale, DFGe- le débit de filtration glomérulaire estimé.

However, the decline rate of eGFR among patients can vary independently of the baseline eGFR ${ }^{6}$. This explains why patients with the same initial stage of CKD may have different course and clinical consequences. Some of them have had stable values of the estimated glomerular filtration rate (eGFR) for several years. This condition can be called stable CKD. In few patients, eGFR increases; it is the so-called reversible CKD. In the majority of patients, however, eGFR decreases over time; that is the progressive $\mathrm{CKD}^{7}$.

A decline in eGFR may serve as an adequate indicator to evaluate the disease severity ${ }^{8}$ and a tool to monitor the adequacy of treatment. The decline rate of eGFR level is an independent predictor of end-stage $\mathrm{CKD}$, which will require renal replacement therapy ${ }^{9}$ and mortality ${ }^{10}$.

A rapid decline in eGFR is determined by a loss of $3 \mathrm{ml} / \mathrm{min} / 1.73 \mathrm{~m}^{2}$ of glomerular filtration throughout the year, which is a threefold average annual decline rate of GFR associated with ageing. It is associated with an increased risk of both cardiovascular and overall mortality ${ }^{11}$. 
Patients, whose eGFR declines by more than 3 $\mathrm{ml} / \mathrm{min} / 1.73 \mathrm{~m}^{2}$ throughout the year, require intensive reno-protective therapy.

Currently, in addition to determining the glomerular filtration rate, the renal functional reserve, which reflects the ability of the kidneys to increase glomerular filtration in response to stimulating factors, is used to assess the functional state of the kidneys ${ }^{12}$. In medical practice, various methods of determining the renal functional reserve are used. However, the prognostic value of the renal functional reserve in patients with chronic kidney disease has not been fully clarified yet. According to the available study findings, the conclusions are contradictory. Some studies indicate that, with the preserved renal functional reserve, it progressively decreases with the progression of $\mathrm{CKD}^{13}$ but can be maintained even at the glomerular filtration rate of $15 \mathrm{ml} / \mathrm{min}^{14}$. Renal functional reserve (RFR) is preserved for at least 90 years, both in men and in women ${ }^{15}$. It is also paradoxical that the renal functional reserve may be absent in patients with preserved or slightly reduced renal function, and vice versa, may be high in patients with low baseline glomerular filtration rate. The preoperative renal reserve determined by dopamine in living donors is associated with a short-term prognosis of kidney function - glomerular filtration rate 3 months after donation, but it does not show an association with the glomerular filtration rate after 5 years $^{16}$.

The objective OF THE STUdy was to improve the efficacy of the prognosis of patients with CKD: to determine the relationship between RFR and the decline in eGFR throughout one-year follow-up, to detect additional prognostically significant factors of CKD progression in determining renal functional reserve via the water-salt loading test with $0.5 \%$ sodium chloride solution at the rate of $0.5 \%$ of the body weight.

\section{Material AND Methods}

The study was approved by the Ethics Committee of the Shupyk National Medical Academy of Postgraduate Education, Kyiv, Ukraine. The study involved patients over 18 years of age with clinical and laboratory data, which allowed to establish the diagnosis of CKD according to the KDIGO 2012 Clinical Practice Guidelines for the evaluation and management of chronic kidney disease of Stage 1-3 (a and b) (decline in GFR to $30 \mathrm{ml} / \mathrm{min} / 1.73 \mathrm{~m}^{2}$ ). Exclusion criteria were patient unwillingness to participate in the study, Stage 4-5 of CKD, pregnancy and active onco-pathology. All patients gave their informed consent to participate in the study.
In a single-centre prospective study, during 3-year follow-up period, from January 2016 to December 2018, 108 patients with CKD of Stage 1-3 (a, b) were examined on the basis of the Municipal Institution of the Kyiv Regional Council „Kyiv Regional Hospital No. 2".

Patients were examined using the standard methods for determination of anthropometric measures, the calculated values of body area and body mass index. The blood pressure was measured. Renal functional reserve was determined using the water-salt loading test with $0.5 \%$ sodium chloride solution at the rate of $0.5 \%$ of the body weight ${ }^{17,18}$. The examination was performed on an outpatient basis in the morning on an empty stomach after a 12-hour fast.

Venous blood was collected to determine serum creatinine concentration. Serum creatinine was used to calculate the baseline glomerular filtration rate using the CKD-EPI (Chronic Kidney Disease Epidemiology Collaboration) equation. The patient emptied the bladder. A urine sample was used to determine the urine creatinine concentration. Then, the patient in the presence of a doctor took orally $0.5 \%$ sodium chloride solution at the rate of $0.5 \%$ of the body weight for $5-7$ minutes and was at rest in a sitting position for one hour. After one hour, venous blood was collected again to determine serum creatinine concentration and urinary bladder emptying. The volume of urine obtained in induced diuresis and the creatinine concentration in it were determined.

According to the formula, creatinine excretion per one hour is calculated:

$$
\mathrm{CE}=\mathrm{Uc}_{\mathrm{c}} \cdot \mathrm{D} 60,
$$

where $\mathrm{CE}$ is creatinine excretion; $\mathrm{Uc}_{\mathrm{c}}$ is the creatinine concentration in the urine portion of induced diuresis collected within 1 hour, expressed in $\mathrm{mmol} / \mathrm{L}$; D60 is the amount of urine collected within 1 hour.

Based on creatinine excretion and the serum creatinine level determined one hour after loading with $0.5 \%$ sodium chloride solution, GFR was calculated based on creatinine clearance:

$$
\mathrm{CC}=\mathrm{CE} / 60 / \mathrm{Pc} \text {, }
$$

where $\mathrm{Pc}_{\mathrm{c}}$ is plasma creatinine concentration.

To calculate a standardized body surface area of $1.73 \mathrm{~m}^{2}$ using the Dubois and Dubois formula, the patient's body surface area (BSA) is calculated on the basis of patient's height and body mass:

BSA $=0.007184 \times$ (height in $\mathrm{cm})^{0.725} \times(\text { mass in } \mathrm{kg})^{0.425}$

Note: The calculations were performed using an online calculator.

Stimulated eGFR is calculated based on creatinine clearance and the actual body surface area:

$$
\text { eGFRst }=U_{c} / \text { BSA } \bullet 1.73
$$


Table 1. Clinical characteristics of patients with CKD stage 1-3 at baseline

\begin{tabular}{cccc}
\hline Parameter & All examined patients & Men & Women \\
\hline Height, $\mathrm{cm}$ & $169.3 \pm 9.2$ & $175.6 \pm 7.6^{*}$ & $163.8 \pm 5.8^{*}$ \\
\hline Mass, $\mathrm{kg}$ & $84.5 \pm 12.7$ & $88.2 \pm 13.1^{*}$ & $80.9 \pm 11.5^{*}$ \\
\hline BMI, $\mathrm{kg} / \mathrm{m}^{2}$ & $29.4 \pm 4.0$ & $28.5 \pm 3.5^{*}$ & $30.2 \pm 4.4^{*}$ \\
\hline Waist line, $\mathrm{cm}$ & $104(98 ; 110)$ & $104(98 ; 110)$ & $104(96 ; 110)$ \\
\hline Systolic blood pressure, $\mathrm{mm} \mathrm{Hg}$ & $150(130 ; 160)$ & $150(135 ; 160)$ & $140(130 ; 165)$ \\
\hline Diastolic blood pressure, $\mathrm{mm} \mathrm{Hg}$ & $90(80 ; 100)$ & $90(80 ; 100)$ & $90(80 ; 90)$ \\
\hline Serum creatinine, $\mu \mathrm{mol} / \mathrm{L}$ & $103.5(83.5 ; 122.8)$ & $114.7(100.5 ; 152.5)$ & $90.1(71.2 ; 107.2)$ \\
\hline eGFR, $\mathrm{ml} / \mathrm{min} / 1.73 \mathrm{~m}^{2}$ & $60.4 \pm 19.9$ & $58.8 \pm 21.4^{*}$ & $62.1 \pm 18.5^{*}$ \\
\hline Serum uric acid, $\mu \mathrm{mol} / \mathrm{L}$ & $316.8 \pm 88.9$ & $312.0 \pm 81.7$ & $321.6 \pm 96.9$ \\
\hline RFR, \% & $74.1(4.7 ; 128.8)$ & $88.8(38.7 ; 152.3)$ & $72.9(-13.2 ; 111.2)$ \\
\hline Change in eGFR throughout a year, $\mathrm{ml} /$ & $-5.6 \pm 10.4$ & $-7.3 \pm 9.7$ & $-3.9 \pm 11.1$ \\
\hline min/1.73 $\mathrm{m}^{2}$ & & &
\end{tabular}

Renal functional reserve is determined by the percentage ratio between stimulated glomerular filtration rate and the baseline glomerular filtration rate:

RFR $=($ eGFRst $-\mathrm{eGFRb}) / \mathrm{eGFRb} \cdot 100 \%$.

In addition, changes in the urine creatinine concentration of spontaneous and induced diuresis were evaluated. Re-examination of patients with determining eGFR was performed in a year. The dynamics of eGFR value throughout the year was evaluated.

Statistical processing of information was carried out using StatSoft Statistica v6.0. and SPSS Statistics 17.0. The mean $(\mathrm{M})$ and standard deviations $(\mathrm{SD})$ were used to evaluate data with a normal distribution; the median value $(\mathrm{Me})$ and quartile range were used to evaluate data with an abnormal distribution (25; 75). To compare unrelated data according to quantitative criterion, nonparametric statistical criteria were used, in particular, the Mann-Whitney U-test for data with an abnormal distribution and the Student's t-test for data with a normal distribution. To compare paired values, the Student's t-test and the Wilcoxon signed-rank test for normal and abnormal distribution were used, respectively. The relationship between parameters was established using a nonparametric measure of rank correlation - the Spearman's correlation coefficient. The results were considered statistically significant with $\mathrm{p}<0.05$. Using tables $2 \times 2$, the change in urine creatinine level associated with the progressive CKD was determined.

Patients aged $29-78$ years participated in the study; an average age was 63 years $(58 ; 70)$. There were 54 men (50\%) and 54 women (50\%). According to the disease stage, the distribution was as follows: Stage 1 was diagnosed in 8 patients $(7 \%)$, Stage 2 in 46 patients ( $43 \%$ ), Stage 3 in 54 patients (50\%). The main characteristics of the examined patients are shown in Table 1.

\section{Results}

The analysis revealed no relationship between the renal functional reserve, stimulated GFR, serum uric acid, urine creatinine concentration in induced diuresis and a decline in eGFR throughout the year. The change in urine creatinine on the background of the water-salt loading was positively correlated with changes in eGFR throughout the year. Spearman's correlation coefficient was rs 0.4 (p-0.02). An increase in urine creatinine concentration of induced diuresis in relation to urine creatinine concentration of morning spontaneous diuresis was observed in 30 patients (28\%) on the background of water-salt loading. A decrease in urine creatinine concentration was observed after the test in 78 patients (72\%).

To evaluate the effect of this risk factor on the decline in eGFR, the patients were divided into 2 groups: patients with rapidly progressive CKD whose eGFR throughout one-year follow-up decreased by $3 \mathrm{ml} / \mathrm{min} / 1.73 \mathrm{~m}^{2}$ and more, and the group with a stable CKD whose eGFR throughout one-year follow-up did not decrease or has decreased by less than $3 \mathrm{ml} / \mathrm{min} / 1.73 \mathrm{~m}^{2}$. The group with progressive CKD included 59 patients and 49 patients in the group with stable CKD. Their main characteristics are shown in Table 2. The patients of both groups are comparable according to the main anthropometric measures (Table 2). They have metabolic disorders, as evidenced by an increase in waistline and body mass index. Significantly higher values of BMI were observed in the stable CKD group compared with the group where eGFR decreased by more than $3 \mathrm{ml} /$ $\mathrm{min} / 1.73 \mathrm{~m}^{2}$ throughout the year.

In both groups, there were no differences in baseline blood pressure, serum creatinine before and after the water-salt loading test, baseline and stimulated eGFR, the state of RFR (Table 3). 
Table 2. Anthropometric measures of patients with stable and progressive CKD.

\begin{tabular}{cccc}
\hline Parameter & Progressive CKD, $\mathrm{n}=59$ & Stable CKD, $\mathrm{n}=49$ & $\mathrm{p}$-level \\
\hline Men & 32 & 22 & \\
\hline Women & 27 & 27 & 0.456 \\
\hline Age, years & $66.5(58 ; 74)$ & $62(59 ; 70)$ & 0.691 \\
\hline Height, $\mathrm{cm}$ & $170.0 \pm 7.9$ & $167.5 \pm 8.2$ & 0.395 \\
\hline Mass, $\mathrm{kg}$ & $83.4 \pm 12.5$ & $88.4 \pm 8.9$ & 0.038 \\
\hline BMI, $\mathrm{kg} / \mathrm{m}^{2}$ & $28.8 \pm 3.8$ & $31.5 \pm 3.8$ & 0.606 \\
\hline Waist line, $\mathrm{cm}$ & $104.5(98 ; 110)$ & $108(101.5 ; 110.5)$ & \\
\hline
\end{tabular}

Table 3. The results of the water-salt loading test to determine RFR and the values of patients after one year.

\begin{tabular}{|c|c|c|c|}
\hline Parameter & Progressive CKD, $n=59$ & Stable CKD, $n=49$ & p-level \\
\hline Systolic blood pressure, $\mathrm{mm} \mathrm{Hg}$ & $150(140 ; 160)$ & $150(140 ; 167.5)$ & 0.500 \\
\hline Diastolic blood pressure, $\mathrm{mm} \mathrm{Hg}$ & $90(80 ; 100)$ & $90(80 ; 100)$ & 0.677 \\
\hline Serum creatinine before the test, $\mu \mathrm{mol} / \mathrm{L}$ & $109.8(91.9 ; 121.6)$ & $101.0(71.9 ; 144.5)$ & 0.692 \\
\hline $\begin{array}{l}\text { Serum creatinine an hour after the water-salt loading test, } \\
\qquad \mu \mathrm{mol} / \mathrm{L}\end{array}$ & $110.2(91.9 ; 129.3)$ & $102.0(72.3 ; 144.6)$ & 0.640 \\
\hline Baseline eGFR $\mathrm{ml} / \mathrm{min} / 1.73 \mathrm{~m}^{2}$ & $55.8 \pm 15.2$ & $58.8 \pm 21.3$ & 0.821 \\
\hline $\begin{array}{l}\text { Stimulated eGFR after the water-salt loading test, } \\
\mathrm{ml} / \mathrm{min} / 1.73 \mathrm{~m}^{2}\end{array}$ & $108.3(67.6 ; 119.9)$ & $96.1(37.7 ; 144.7)$ & 0.636 \\
\hline RFR, \% & $87.4(37.1 ; 120.1)$ & $59.9(-21.7 ; 121.3)$ & 0.444 \\
\hline Urine creatinine in spontaneous diuresis, $\mathrm{mmol} / \mathrm{L}$ & $10.5(7.9 ; 11.5)$ & $7.6(4.8 ; 9.9)$ & 0.056 \\
\hline Urine creatinine in induced diuresis, $\mathrm{mmol} / \mathrm{L}$ & $7.2(4.9 ; 9.4)$ & $7.0(5.3 ; 9.2)$ & 0.747 \\
\hline $\begin{array}{c}\text { Change in the urine creatinine concentration during } \\
\text { the loading, } \mathrm{mmol} / \mathrm{L}\end{array}$ & $-2.05 \pm 2.5$ & $-0.18 \pm 2.1$ & 0.019 \\
\hline eGFR after a year, $\mathrm{ml} / \mathrm{min} / 1.73 \mathrm{~m}^{2}$ & $43.4 \pm 15.2$ & $61.1 \pm 25.1$ & 0.009 \\
\hline Change in eGFR throughout a year, $\mathrm{ml} / \mathrm{min} / 1.73 \mathrm{~m}^{2}$ & $-12.4 \pm 8.3$ & $2.4 \pm 5.7$ & $<0.0001$ \\
\hline
\end{tabular}

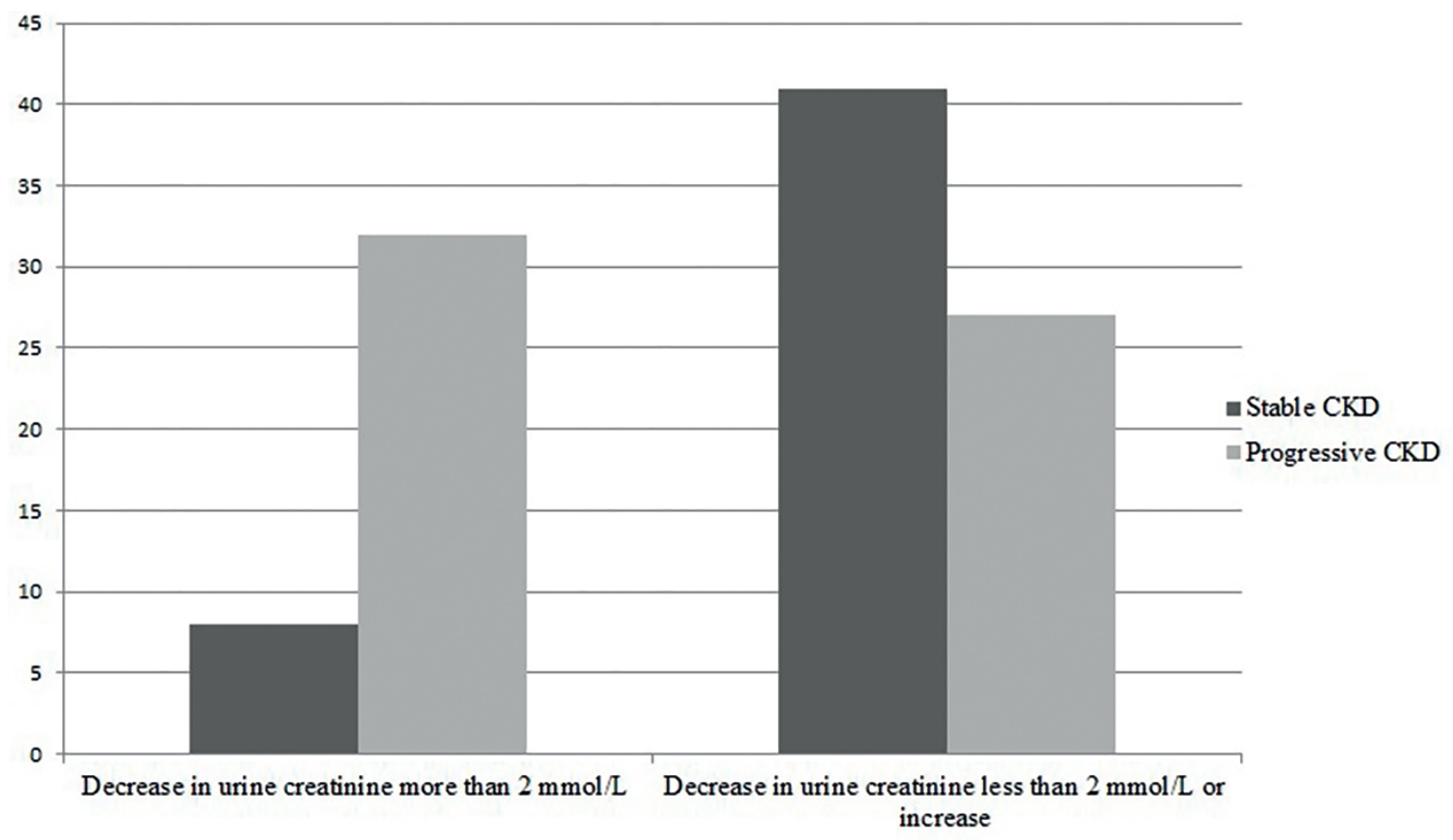

Figure 1. The ratio of patients depending on the change in urine creatinine concentration and the course of CKD. 
Patients with progressive CKD had significantly lower values of eGFR after one-year follow-up (p-level $<0.0001$ ). Urine creatinine concentration decreased on the background of the water-salt loading (p-level 0.002). In patients with stable CKD, the values of eGFR did not statistically differ at the beginning of the study and after one-year follow-up, and there was no significant difference between the spontaneous creatinine concentration and induced diuresis on the background of the water-salt loading test. Using the odds ratio (OR), we revealed the change in urine creatinine level which is associated with the risk of decline in eGFR by more than $3 \mathrm{ml} / \mathrm{min} / 1.73 \mathrm{~m}^{2}$ throughout the year (Figure 1): OR with a decrease in urine creatinine level by more than $2 \mathrm{mmol} / \mathrm{L}$ was 4.7 (95\% CI 1.9-12.0).

\section{Discussion}

No studies on the relationship between the state of RFR and decline in eGFR have been found. The findings suggest that the ability of the kidney to respond to stressful factors by increasing glomerular filtration is not decisive in maintaining eGFR throughout the year. This is due to the fact that available findings of both the historical and relatively recent studies show that, over time, the role of the main effector in the progression of CKD has passed from the glomeruli, which are responsible for the increase in GFR in response to provoking stimuli, to the interstice. However, the state of the renal functional reserve should be taken into account for the individualization of reno-protection strategy $y^{19-21}$. At the same time, the prognostic value of the change in urine creatinine concentration, before and after the water-salt loading test with $0.5 \%$ sodium chloride solution at a rate of $0.5 \%$ of body weight, was revealed. The ability of the kidney to maintain or increase the urine creatinine concentration under the influence of the stress factor is associated with a stable course of CKD when eGFR decreases by less than $3 \mathrm{ml} / \mathrm{min} / 1.73 \mathrm{~m}^{2}$ throughout the year.

\section{Conclusions}

With improving the functionality of the test to determine the renal functional reserve as a routine method of examination of nephrology patients, it is possible to individualize the prognosis of a particular patient according to the progression of chronic kidney disease, to identify the high risk group for disease progression and to intensify therapy and monitoring of kidney function by determining the change in the urine creatinine concentration.

\section{Compliance with Ethics Requirements:}

„The authors declare no conflict of interest regarding this article"

„The authors declare that all the procedures and experiments of this study respect the ethical standards in the Helsinki Declaration of 1975, as revised in 2008(5), as well as the national law. Informed consent was obtained from all the patients included in the study"

"No funding for this study"

\section{References}

1. Coresh J, Selvin E, Stevens LA, et al. Prevalence of chronic kidney disease in the United States. JAMA. 2007;298(17):2038-2047.

2. Narres M, Claessen H, Droste S, et al. The incidence of end-stage renal disease in the diabetic (compared to the non-diabetic) population: a systematic review. PLoS One. 2016;11(1):e0147329.

3. Crews DC, Plantinga LC, Miller ER 3rd, et al. Prevalence of chronic kidney disease in persons with undiagnosed or prehypertension in the United States. Hypertension. 2010;55(5):1102-1109.

4. Levey AS, Coresh J, Bolton K, et al. National Kidney Foundation. KDOQI clinical practice guidelines for chronic kidney disease: evaluation, classification, and stratification. Am J Kidney Dis. 2002; 39(Suppl 1):1-266.

5. Levin A, Stevens PE, Bilous RW, et al. Kidney Disease Improving Global Outcomes (KDIGO) CKD Work Group. KDIGO 2012 clinical practice guideline for the evaluation and management of chronic kidney disease. Kidney Int. 2013;3(1):1-150.

6. Tsai CW, Ting IW, Yeh HC, Kuo CC. Longitudinal change in estimated GFR among CKD patients: A 10-year follow-up study of an integrated kidney disease care program in Taiwan. PloS one. 2017;12(4):e0173843.

7. Chevalier RL. The proximal tubule is the primary target of injury and progression of kidney disease: role of the glomerulotubular junction. Am J Physiol Renal Physiol. 2016;311(1):145-61.

8. Sheen YJ, Sheu WH. Risks of rapid decline renal function in patients with type 2 diabetes. World Journal of Diabetes. 2014;5(6): 835.

9. Rosansky SJ. Renal function trajectory is more important than chronic kidney disease stage for managing patients with chronic kidney disease. American Journal of Nephrology. 2012:36(1):1-10.

10. Al-Aly Z, Zeringue A, Fu J, et al. Rate of kidney function decline associates with mortality. Journal of the American Society of Nephrology. 2010;21(11):1961-1969.

11. Rifkin DE, Shlipak MG, Katz R, et al. Rapid kidney function decline and mortality risk in older adults. Archives of Internal Medicine. 2008;168(20):2212-2218.

12. Sharma A, Mucino MJ, Ronco C. Renal functional reserve and renal recovery after acute kidney injury. Nephron Clinical Practice. 2014;127(1-4):94-100.

13. Bosch JP, Saccaggi A, Lauer A, et al. Renal functional reserve in humans: effect of protein intake on glomerular filtration rate. The American Journal of Medicine. 1983; 75(6):943-950.

14. Barai S, Nalesso F, Meola M, et al. Functional renal reserve capacity in different stages of chronic kidney disease. Nephrology. 2010;15(3):350-353. 
15. Fliser D, Ritz E, Franek E. Renal reserve in the elderly. Seminars in Nephrology. 1995;15(5):463-467.

16. Van Londen M, Kasper N, Hessels NR, et al. Renal func tional reserve capacity before and after living kidney donation. American Journal of Physiology-Renal Physiology. 2018;315(6):1550-1554.

17. Hozhenko AI, Kravchuk AV, Sirman VM, Nikitenko OP, Romaniv LV. Functional renal reserve: physiological value of renal reserve and substantiation of the method of its determination. Kidneys. 2015;4(14):7-11 (in Ukrainian).

18. Stoicescu M, Csepento C, Mutiu G, Bungau S. The role of increased level of plasma renin in etiopathogenic arterial hypertension in the young. Romanian Journal of Morphology and Embriology 2017;52(Suppl. 1):419-423.

19. Ivanov DD, Gozhenko AI, Savytska LM. Renoprotection and its association with eGFR and renal functional reserve. Kidneys. 2018;7(4):11-17 (in Ukrainian).

20. Diaconu C, Balaceanu A, Bartos D. Diuretics, first-line antihypertensive agents: are they always safe in the elderly? Romanian Journal of Internal Medicine 2014;52(2):87-90.

21. Manea M, Marcu D, Pantea Stoian A, et al. Heart failure with preserved ejection fraction and atrial fibrillation: a review. Rev Chim (Bucharest). 2018;69(11):4180-4184. 